\title{
Model Development Planning Policy Tourism District of Tanah Laut
}

\author{
Sihabuddin Chalid ${ }^{1 *} \quad$ Bambang Koesbandrijo $^{2}$ \\ 1.The State Polytechnich of Tanah Laut, Jl. A. Yani Km. 6 Pelaihari Tanah Laut South Kalimantan, Indonesia \\ 2.University of August 17, 1945 Surabaya, Jl. Semolowaru 45 Surabaya 60118, East Java, Indonesia
}

\begin{abstract}
Tanah Laut Regency is endowed coastal areas along the $200 \mathrm{~km}$, has the potential to become a tourist destination. There are several beaches, waterfalls, and other attractions. Although the government issued Regulation No. 5 in 2015, nevertheless, this area has not become a significant tourist destination, because the regulation made yet implemented optimally. Nowadays the tourism sector is including businesses that give economic improvement to the community. The technique used in this study is a qualitative descriptive. The consequences of this study are as follows; that the Implementation of Tourism Development Policy in Tanah Laut Regency is not optimal. Provincial Regulation on tourism development has not run optimally, the Department of Tourism, which has the authority to formulate resources, have not been many results for the advancement of tourism. Inhibiting factor is that regents have not been severe in developing the potential of tourism in Tanah Laut Regency. In order to realize the objectives and purposes of the development of tourism in Tanah Laut, decree needs to formulated as the basis for realizing consensus-collaborative models of policy planning. Policy planning with the principle of citizen participation, all parties is in the same position and proportional considering the dominant actors and professional competence in order to develop a more integrated, independent necessary implementing agency, resulting in a synergy of all stakeholders in realizing a superior tourism development goal.
\end{abstract}

Keywords: Tourism Development, Policy, Planning Model, Tanah Laut

DOI: $10.7176 /$ PPAR/9-3-11

Publication date:March $31^{\text {st }} 2019$

\section{Preliminary}

Tanah Laut is one of 13 districts in the province of South Kalimantan, Indonesia. The district capital located in Pelaihari which is the center of Tanah Laut Regency. This district has an area of $3631.35 \mathrm{sq} \mathrm{km}$ and a population of as many as 340909 people, (census in 2017). Tanah Laut has considerable potential in the improvement in the economic field, with a coastline of $1,631.35 \mathrm{~km}^{2}$ potentials of fisheries, livestock, and agriculture, spread in 11 (eleven) districts and 24 coastal villages, it is more important is to have the grace of wealth of natural resources, which can be a source of prosperity through tourism development.

A wealth of natural resources, which once held in the form of timber, mainly in two districts, Jorong and Kintap, nowadays almost extinct, but the surrounding communities remain poor, because of only a minority. Now the coal mines that have been worked on from 1980, both local investors and foreign national has been exploited on a large scale, which partially abandons the remnants of the hollow ground without reclaimed, and the planting of trees as before. Therefore, Tanah Laut District government, to improve social welfare district government began working to increase sources of revenue through tourism.

Tourism development which based on resources, which already owned, such as the famous beach used by beaches Takisung. Takisung in the district, sub-district Swarangan beach, and coastal Jorong, Panyipatan, Batakan in the district. To serve as the other tourist destinations, in other districts have two mountain which has a waterfall in the district Bajuin, in the form of cultural tourism in the district swamp buffalo Bati-Bati and several other cultural attractions.

Tanah Laut as a tourist destination has long been made, to improve the local economy through sustainable tourism development, and increase revenue, some policies issued, Regulation No. 5 of 2014 on Regional Tourism Development Master Plan Tanah Laut Regency. Furthermore, Regional Regulation No. 5 Year 2015 concerning the Implementation of Tourism as a basis in determining policy towards the development of tourism, which can be used as guidelines for the implementation of tourism, so tourists is increasing, but in period of the last 3 years the increase in tourists, both domestic and foreign tourists have not been many. While in other areas in Indonesia have implemented to set the target number of tourists.

Finally, this study will examine the problem, how the tourism development planning policy implemented in Tanah Laut. The desired goal of this research is to find a model of tourism development policy planning, Tanah Laut Regency, to provide input for the development of the concept and Tourism proper development model, the lifting tourism in Tanah Laut Regency. 


\section{Literature Review}

\subsection{Development of Tourism Destinations}

The development of tourism has been recognized as one of the key sectors for development in many countries and a significant source of income, jobs and wealth creation(Drakulić Kovačević, Kovačević, Stankov, Dragićević, \& Miletić, 2018). The study of tourism development has been characterized by a troubled dialectic between applied studies of tourism's contribution to economic development and theoretically-informed political economy analyses(Bianchi, 2018). Rapid changes in the competitive environment in tourism have forced tourism destinations to provide higher quality services and added value to travelers (Martínez, Galván, \& Lafuente, 2014).

Furthermore, the development is a process of change that includes the entire social system, such as politics, economy, infrastructure, defense, education and technology, institutional, and cultural (Alexander 1994). Portes (1976) stated the development as the transformation of economic, social and cultural. Development is a process of planned changes to improve various aspects of community life according to Deddy Tikson T. (2005) that national development can also be interpreted as the transformation of economic, social and cultural deliberately through policies and strategies towards the desired direction.

However, the destination managers must consider whether to continue to consolidate their experiences and markets or innovate by developing new experiences and targeting new markets when planning their tourism destination development(Gardiner \& Scott, 2018). The transformation of the economic structure, for example, can be seen through the increase or rapid production growth in industry and services, so that its contribution to the national income increases. Instead, the contribution of the agricultural sector will become increasingly smaller and inversely proportional to the growth of industrialization and economic modernization social transformation seen through the distribution of prosperity through equitable access to socio-economic resources, such as education, tourism, housing, clean water, recreational facilities, and participation in the political decision-making process. The potential economic benefits of tourism in regions or countries have been a recurrent topic in the tourism research literature(Andrades \& Dimanche, 2017).

Thus, the development process occurs in all aspects of community life, economic, social, cultural, political, which take place on a macro level and micro. The significance of the development is the lack of progress, growth, and diversification - the basic pattern of development that takes into account the real space (physical and nonphysical). The room should be defined in a holistic manner, the consideration of the administrative-territorial integrity, economic, historical and empirical. So that the basic pattern of development can be patterned comprehensively, taking into account seriously the condition and potential of the region, both natural and human environment (Tantra, 2014).

Associated with the development of tourist areas of local, regional and national levels is closely related to the economic development of the region, in other words, the development of tourism in a tourist area always will be offset by the benefit of local communities. Development of tourist areas where the tourism industry will develop well and have positive impacts on the area, create jobs, it will even happen new demand of agricultural products, crafts, and education in serving the tourists. For the development of tourism is defined as a way of developing destinations, tourist areas and attractions for the better and give a positive impact on society, the government, the tourism industry, and tourists.

According to Grady in Suwantoro (2002), the criteria for tourism development should always involve the local community and can provide a benefit for the local community, not undermine the values of social and cultural, as well as the number of visits to tourist attraction does not exceed the capacity of the social order to the negative impact arising can minimize. Such criteria emphasize the development of community-based tourism (community-based tourism) and the development of sustainable tourism (sustainable tourism development). The principles of sustainable tourism development mandated by Law No. 10 of 2009 namely; promote economic growth, improve people's welfare, eliminate poverty, unemployment, preserving nature, the environment, and resources.

\subsection{Tourism Policy and Implementation}

Tourism planning and policy is, arguably, one of the most significant influences on how tourism develops, who wins and loses, and how benefits and impacts of tourism are distributed(Dredge \& Jamal, 2015). Tourism destinations are dynamically complex systems in which behavior is controlled by many interacting components and feedback loops(Mai \& Smith, 2018). The context in the tourism policy agenda setting in which these policies made and implemented (Kitson, Ahmed, Harvey, Seers \& Thompson, 1996). According to Walt (1994), influential factors in the context of the policy consists of factors situational (events and political changes of government), structural factors (the political system, economic structure, demographic), culture (ethnic, racial, language) and international factors (globalization). The comprehensive policies may have more complex and profound effects on tourism development(Deng, Hu, \& Ma, 2019).

The public participation is considered a cornerstone of sustainable tourism planning(Lin \& Simmons, 2017). 
Tourism policy was never given the importance of other industries such as agriculture, despite generating much more wealth(Estol \& Font, 2016). According to the policy triangle model (Walt and Gilson, 1994), the actor is those who are at the center in the policy framework. Actors in policy usually affect the process at the central, provincial and district/city. They are part of a network whose role is to decide on a tourism policy of each level (Walt, 1994). The political role touted as one of the ways the actors in decision-making that led to the birth of tourism policy, how much compromise reached in this process.

The policy process is a series of processes of initiation, development or formulation, negotiation, communication, implementation and evaluation of a policy (Sutcliffe and Court, 2006). Step in formulating the policy process to make choices and establish priorities that take precedence. Elections in making decisions in policy should be carried out in detail and undertake the specific electoral process; it makes the decision can implement (Sutton, 1999).

The policy development process is done by collecting, processing, and disseminate information relating to the policies that will be developed, promoting options for steps to be taken, implement, and evaluate. In studying the policy process known heuristic stages, the choice of the policy process into tiers by using theories and models are intended to allow the electoral process does not represent conditions that occur in the actual situation. Steps in stages heuristic by Pollard and Court (2005) are as follows: 1) identification of problems and the introduction of the introduction of the situation (the new thing) to know the magnitude of the problem, 2) policy formulation by step exploration of actor formulation of policies, 3) implementation Policy,

Implementation of the policy defined as what is happening in line with expectations and the perceived effect of policies (DeLeon, 1999). In the implementation of the policy, it is seen whether there is a gap between policy planning with what happens as a result of the policy. The case study on the impact of a various policy that aims to measure the success of policy the implementation should be applied. In addition, Korten (in Tarigan, 2000: 19) Model Conformance is implementing the policy or program by using the learning process approach. This model cored match between the three elements in the implementation of the program, the program itself, the implementation of the program and the target group of the program.

Figure 2.1: Model of Conformity

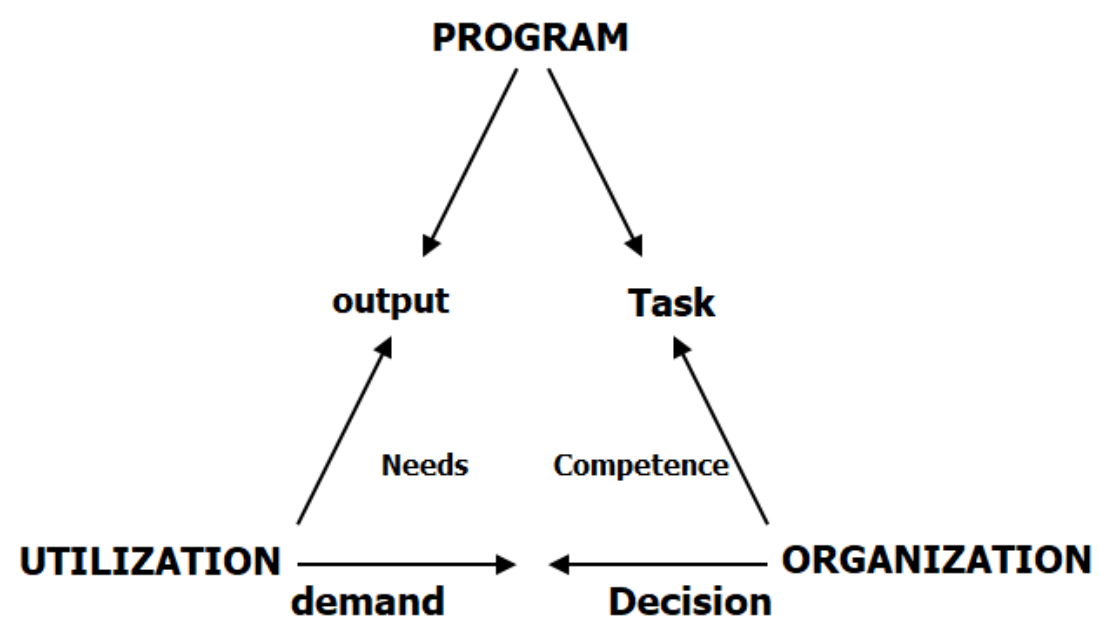

Source: David C. Korten (1988) in Tarigan, p. 19

Korten states that a program will successfully be implemented if there is conformity of the three elements of the program implementation. First, the correspondence between the program beneficiaries, for instance, the correspondence between what is offered by the program with what is required by the target group (beneficiaries). Second, the agreement between the program by implementing organizations, namely the correspondence between the tasks required by the program with the capability of implementing organizations. Third, the agreement between groups of users by implementing organizations, namely the correspondence between the conditions for the organization decided to acquire the program output with what can be done by the target group.

Based on the pattern developed Korten, it is understood that if there is no match between the three elements of policy implementation, the performance of the program will not work by what is expected. Normally, the program with the output does not match with needs of target groups, the output cannot be utilized. If the implementing organization cannot carry out the task required by the organization's program cannot deliver output with the proper program. Alternatively, if the target group cannot meet the conditions laid down implementing organization the target group does not get the program output. Therefore, the agreement between the three elements of policy implementation is necessary so that programs run under the plans that have been made. 


\subsection{Collaborative Planning Model}

As part of the development process that has undergone a paradigm shift, planning is also undergoing a paradigm shift towards planning based on the communication to be a critical element in development based collaboration. At first, the plan is based on instrumental rationality, which is known as rational planning (Banfield, 1959). However, this approach often ignores political reality, so Charles Lindbloom (1959) proposed the idea of disjointed incrementalism and Amitai Ezioni (1967) with the idea of Mixed-scanning. Although there is a change in approach, planning still involves only thinkers and decision makers. On the other hand. Therefore, in another case, the determinant of tourism flows is the relative prices in the destination country and the origin country (or even a set of competing destinations)(Agiomirgianakis, Serenis, \& Tsounis, 2017).

The development process is no longer be a ruling government - further, the criticism that the development only a vested interest will the government realize the need for communication and joint action with stakeholders. Also, this has led to the emergence of thinking collaborative governance (Anshell \& Gash, 2007; Innes \& Booher, 2010), where stakeholders sit together to take a public decision that represents a consensus through a process of dialogue face to face, the result of planning and consensus through dialogue process democraticallyface. As has been shown in the position of collaboration in the planning process of communication-based on the image below:

Figure 2.5 Position-Based Planning Process Collaboration in Communications

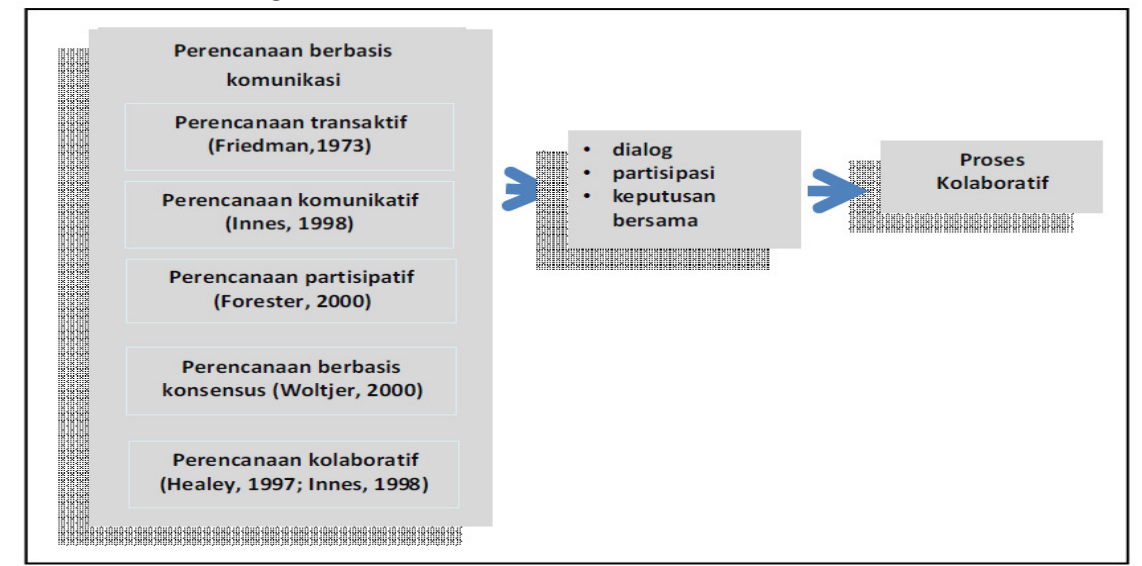

Source: Sufianti, 2013

Collaborative planning is the decision-making process in which the various stakeholders, who see problems from different angles, sit together to explore their differences constructively, and then look for a solution, and to get more than what is obtained if only find solutions on their own, Collaborative planning is based on planning communication (communicative rationality). The understanding gained from some opinions: that the collaborative planning is a planning-oriented stakeholder, involving stakeholders (Healey, 2006; Allmendinger and Tewdwr Jones, 2002) is not limited by place and time (Graham and Healey, 1999), based on the concept structuralist of Gidden and communicative action of Habermas (1984), in the process involves the process of communication, dialogue, and transactive (Graham and Healey, 1999; Healey, 2006).

Linkages with the planning of tourism management in Tanah Laut Regency, scrupulous, because with this policy, the resulting program does not generate a pseudo-democracy but profitable communities. Local traditional buildings are important tourist attractions, among which some have even been listed as world heritage(Wang \& Yotsumoto, 2019). Thus the process of planning collaboration results from true collaboration with the three stakeholders, namely the executive, program and beneficiaries. As in the following figure:

Figure 2.6 The success of the Collaborative Process and Communication-Based Planning 


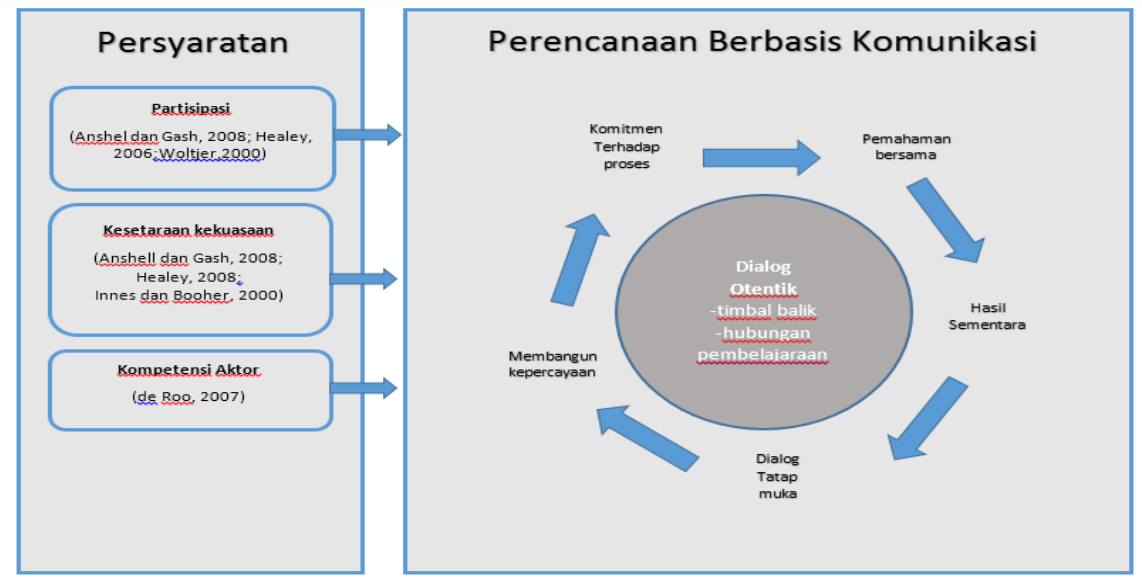

(Source: adapted from Ansell \& Gash, 2008; Innes \& Booher, 2000 (in Ely Sufianti, 2013).

Image above confirms that planning is needed to solve the problems that tend to be protracted or intractable complexity and involves many parties therein. Rittel and Webber (1973) stated that planning problems are wicked problems. Said to be the wicked not because the problem is reprehensible, but in the sense that the problem is "related" to the hazard (malignant), malignant (vicious), or complex (tricky). Practically, collaborative planning is particularly useful for solving "wicked problems" in the sense that it involves many parties, beyond the boundaries of administrative governance, and that is difficult to reach an agreement (Innes and Booher, 2010). One of the problems that are "wicked" is the environmental issue.

\section{Research Methods}

The method used in this study is a qualitative method. The essence of the method according to Burhan (2014) (1) is an ontological, postpositivism are critical realism that sees social reality there is in fact in accordance with the laws of nature, but an impossible thing when a social reality can be seen correctly by humans (researchers). (2) methodological approach to experimental observation is not enough to find the truth of the data, but must use a triangulation method, which uses a variety of methods, data sources, researchers and theories. (3) the epistemological relationship between the observer or investigator with the object under study or social reality cannot be separated.

Moreover, as stated by Moleong, qualitative methods carried out by a number of considerations, the first adjusting qualitative methods more easily when faced with a double reality; second, this method presents a direct relationship between the researcher and the informant; Third, this method is more sensitive and more able to adjust to much sharpening influences together and to patterns of face value. Bogdan and Biklen (2007) suggested that the characteristics of qualitative research are: (1) nature, (2) the data is descriptive not numbers, (3) data analysis with inductive and (4) the meaning is fundamental in qualitative research.

Creswell (2010) states that qualitative research is a process of scientific research that is intended to understand the problem of human problems in a social context by creating an overall picture and the complex presented, reported the views in detail of the resources, and conducted within a setting that naturally without any intervention from the author.

Studies conducted in Tanah Laut Regency will be devoted to the formulation of tourism development models. Informants selected purposively, in hopes of obtaining information from the right source by what the informant know about something. The informant in this research is the official Department of Tourism, board members policymakers tourism, implementor of policies, community leaders, NGOs and tourism players in the district of Tanah Laut, after collecting data, researchers will carry out an analysis of how the implementation of policies Tourism then the outcome as the basis for a model.

\section{Results and Discussion}

Policy development of tourism in Tanah Laut Regency formulated with a top-down manner without involving community participation. Policy and 2017 have not been implemented optimally. Although not yet implemented no severe criticism of society. It happened because of the people of Tanah Laut Regency is still sticky with paternalistic culture. Regents to act more as a paternalistic leader to run governance by his will. Consequently a relatively low level of public participation for their inequalities of power. In the district of Tanah Laut occur politicization of bureaucracy and abuse of authority and integrity of the policy elite imaging lower officials.

Communication and dissemination of policy implementation in the development of tourism promotion activities are still minimal. Forms of government support Tanah Laut not optimal in the development of tourism. Social, economic, political and are not conducive to the main problem of the failure of policy implementation. 


\subsection{Analysis of Implementation}

Based on data and field information indicates that coordination is a powerful mechanism in the implementation of public policy. The better the coordination of communication between the parties involved in the process of implementation, the assumption errors will be minimal to happen, vice versa. Coordination takes place between the Department of Tourism Tanah Laut with the relevant authorities did not go well as their coordination with the Planning Board (Bappeda) that is in the planning process, the Department of Public Works (PU) is in the form of infrastructure development other support, the Office transportation in road development plan, plan the route of sea transport.

Tanah Laut tourism office is not optimal in the dissemination of policy implementation in the development of tourism through promotional activities. Socialization and marketing communications Tanah Laut do not get out of the scope of the promotion. Tourism in communicating communication model tourist attraction in Tanah Laut include:

1) Promotion in the form of Personal selling, which communicates directly face to face between the Department of Tourism to tourists in order to establish an understanding of the attractions such as exhibitions and events, exhibitions are usually held their own or participate in exhibitions in other areas.

2) Advertising is a form of indirect communication are based on information about the benefits of a tourist attraction in Tanah Laut. Arranged such that cause a sense of fun and visit.

3) Direct marketing interactive promotional mix, utilizing an advertising medium for trigger the measurable response and transaction all locations, a direct marketing promotional communications addressed to the individual consumer, through website/internet and CD/DVD.

Model communication implemented through promotion in the form of personal selling, advertising, direct marketing. Problems that occur are less optimal enforcement authorities disseminate causing the information conveyed less than the maximum. The consistency of communication will help communication to the Department of Tourism so the public can easily understand it. The recipients of the communication society can well understand the intent and purpose of being discussed. The consistency of communication can prevent wrong information from the Tourism Office in the field.

\subsubsection{Conformity the Program with Implementer}

Based on Regulation No. 5 in 2015, the development of tourism in Tanah Laut, the implementer of critical actors in implementing the Tourism Policy in Tanah Laut is the local Tourism Office. As the primary implementing agency, the Department of Tourism Tanah Laut Regency demanded the division of tasks and functions are clear of each organizational unit in order to achieve the policy objectives. In regulation No. 52015 explained that the tourism business is entirely given to the local Tourism Office, it is appropriate that the regional regulation Tourism Office function is to assist the Regent of cultural affairs and tourism.

Department of Tourism as executor is tough to prioritize the real and the ideal conditions in implementing the program. Although in this case, the Department of Tourism has tried to convince the stakeholders, especially the regents to be accommodated the necessary budget, with unmet budget according to priorities planned in the program, this has an impact on the implementation of activities. Because of the program is not in line with the needs of development that has been poured in by implementing the strategic plan, both on aspects of the budget directly in contact with capital expenditure and recurrent expenditure such as human resource development activities and budget for coordination, other promotions.

Also, the findings of researchers found that the Department of Tourism Tanah Laut does not have Standart Operational Procedure (SOP). The binding procedure in the stages of implementation of activities, as a guide in every implementation and policies that have been made, but because there is no SOP so that in carrying out its duties and responsibilities they are based only on the policies listed in the Strategic Plan of the Department. Consequently, have an impact on the occurrence of multiple interpretations or distortions between the various parties is the conflict between the implementation agency.

Budgets are contained in the DPA as financial resources in addition to Human Resources and Resource Time. It turned out that the district government from 2015 to 2017 did not include explicitly budget capital expenditure, namely in tourism development - conversely, First Target and Actual Receipts Tanah Laut Regency year 2017 budget in education office regarding Tanah Laut District Tourism Department which levies a place Recreation and Sports in 2017. Furthermore, only 245 million Rupiah (IDR), because the success of a program is determined also by constraints of time defined, the short-term settlement for each annual work program, the medium-term of five years in the completion of the strategic plan.

From the empirical facts can be analyzed, that the capability of the apparatus, Tanah Laut District Tourism Department, as a policy implementor of tourism development is still not optimal. Not only because the aspect of educational qualifications, although practically already have a good understanding of the development plans that have been set, the integrity of the implementing activities should also continue to be refined. Of course, many things that can affect the integrity of the implementing activities, as individuals need to strengthen the individual to be carried out with the specific training and skills, the provision of professional personnel, recruit and retain 
competent staff, and pay attention to the structure and composition of an adequate formation.

Policy development of tourism in Tanah Laut Regency, of course, requires budgetary support in the areas of implementation. Budget support mainly contained in document DPA tourism department became so crucial because the enforceability of the entire program accelerated the development of tourism rests on the availability of the budget to finance various development programs and projects. In achieving the target is not a synergy with the program; because of the absence of a budget and not optimal local government land-sea prioritize the development budgets for programs to run by the plans made.

\subsubsection{Conformity the Beneficiary with Program}

Gerston (2010) states that funds may still be required to guarantee enforcement of the new policy. Besides, the implementation is not easy work. The difficulty can be a limited supply of funds needed to implement the program that has been set. Funding is a critical element of being a policy decision to run. Therefore, Wahab (2012) said that the regulatory programs, the funds required to hire or personnel and to allow for technical analysis needed to make regulations, administers the licensing program and monitoring its implementation. Funding is also one of the critical success factors of Tourism Policy Implementation in Tanah Laut. Tourism Act No. 10 of 2009 Article 57 states that "funding is the responsibility of the area of tourism in the district of Tanah Laut."Furthermore, the work program 2018 that received a budget for recurrent spending amounting to 1.084 billion Rupiah (IDR), which is only a little capital expenditure.

Also, the implementation of the interactive nature of the activity that preceded the tourism area in Tanah Laut Regency established. In essence, the policy implementation is not just an administrative process that translates into action a policy of administrative routine. However, also as a political process involving a variety of conflicts of interest. Thus, the quality policy cannot be seen as solely determined by the performance of the bureaucracy, but also influenced by the political dimension that surrounded him. In connection with it, the political situation is developing in Tanah Laut is not conducive to the effectiveness of the Tourism Policy Implementation. Therefore the implementation of the program depends on the budget provided by the district land of the Sea, so elements of society, Institutions,

Thus it can be said to fit between the implementers and beneficiaries cannot be said to be appropriate. It was seen by the implementation of the Tourism Policy in Tanah Laut Regency more likely to use a top-down approach. As a result, the space for community participation is minimal. Networking in promoting tourism in Tanah Laut Regency very limited, Performance implementer of policy is not optimal. The limitation quantity and quality of human resources available and the sectoral ego are still extreme so that coordination and communication have not been effective, and the Social Environment, Economic and Politics wrap circulation of people's lives in Tanah Laut tend to inhibit effective policy implementation.

From the above description can be analyzed that these conditions show commitment and understanding of some people who have not been up to tourism so that tourism issues always offers a variety of increasingly acute problem and the more challenging to resolve. Apart from the various problems that arise and are in handling local government through relevant SKPD, considering the characteristics of objects and attractions, and tradition, as well as the travel market, demands faced, the development of tourism in Tanah Laut Regency always taking into account some principles namely; the principle of continuity (sustainability).

\subsubsection{Conformity Implementor with a beneficiary}

Concerning the authority in the management of tourist destinations in Tanah Laut, informants of elements legislators reveal that up to now there are no clarity parties responsible in the management of tourist areas. As happened in the beach area of Tanah Laut, whereas the existing regulation of regents, but until now no explicit management, and no one SKPD was responsible in the management of coastal areas Land of the Sea, which is a significant tourist destination.

In other word, between the executive and utilized in sync no universal agreement in the utilization of tourist areas, especially for the improvement of the development towards the better. The impact of the absence of a budget provided by the local government, the implementation of regional tourism promotion has not worked optimally, can be seen from the data of tourist arrivals and local tourists who visit Tanah Laut. Elements of tourism promotion are expected to be the primary tool to the destination to Tanah Laut. Based on the findings generated, indicating that most people had mindset tourism as expected, so it affects the effectiveness of the role of local government as a motivator and dynamic factor in the development of tourism.

This is implies that the Department of Tourism as implementor of policies so understand that there are different groups of stakeholders (beneficiaries) to the policy of tourism development, which in itself will assist the Department of Tourism in developing the tourism sector. Consequently, the excellent cooperation through the involvement of active groups such interest in the various work programs which has been formulated, it will be easier for local governments to accelerate the achievement of the purpose of the development of tourism in Tanah Laut Regency, under the coordination of the Department of tourism Tanah Laut.

Therefore, from interviews can be analyzed, because legislators also have the right budget, planners and controlling, the political approach in determining the target cannot be ignored. Parliament has a constituency to 
fight for their aspirations, so sometimes no longer focused on the actual orientation to the goals and objectives. It is mixed with the interests of regional heads, who also is a political official.

Accordingly, the right Parliament strongly supports tourism development program. So that the implementation stages of tourism development program will be supported by an elite who have interests extent to which people receive benefits. Notable here is that if an activity has been designed with bright, from its nomenclature as well as the performance targets and objectives, in other words, meet technocratic aspect and the bottom-up approach is straightforward, then the owner of the authority through challenging to influence. Seeing these two strategic points also exist at the local government level in the flow of tourism development policies primarily implemented by the Department of Tourism, with the structure, duties, and functions are prominent and well established.

Under these circumstances it can be said that the implementation of policies for Tourism Development in Tanah Laut Regency has not run optimally. It looks cooperation and coordination between the government and the public has not been maximized. Conflict arises in the status of coastal land Attraction in Tanah Laut Regency. Inadequate facilities and infrastructure. Human resources support resource development of tourism in Tanah Laut Regency, but generally not professional and has not received adequate financial support from the government.

\subsubsection{Supporting and Inhibiting Factors}

Researchers found several factors supporting and inhibiting factors in the implementation of tourism development strategy by the Department of Tourism in Tanah Laut.

\subsubsection{Supporting factors Attractions Tanah Laut}

Based on the results of field research that the factors that support them in the development of natural tourist attraction Land of the Sea are the policy of tourism development in the form of regulations, it is the vision and mission development. Their foundation and structural work contained in the duties and functions of the constitutional principle, formulate and establish their authority and management of the sources of funding and resources,geographical location, has a wealth of natural attractions, cultural and artificial, culture, public openness towards tourists, right security conditions, a variety of naturally uniqueness / attractions.

\subsubsection{Obstacles Attractions Tanah Laut}

Tourism development in Tanah Laut face some potential problems as an inhibiting factor. It follows the inhibiting factors include; Regent who have serious potential to develop tourism in Tanah Laut Regency. The high sectoral ego, the budget allocation for development is still shallow, thus inhibiting tourism development program that has been created. Unavailability of budget and resources in the education office to engage in synergy, yet their work programs and targets that were targeted implementation of policy implementation program. Means, support facilities in various area attractions that are not maximized. Lack of perception, coordination, and communication intensive. The lack of awareness to take care of tourism is also not owned by the tourists; it appears there was some trash that exists in various tourist areas.

Moreover, yet their Standard Operating Procedures (SOP), specifically that govern progression in Tanah Laut tourism. As we know the policy guidelines still refer to the decree of Main Duties and Functions. The government has yet to make special rules related to the development of tourism in Tanah Laut. Lack of transport to reach every attraction and has not netted networking and synergy among relevant agencies.

\subsubsection{Policy Planning Model Tourism Development Program Tanah Laut}

Based on the theory of collaborative governance Ansell \& Gash (2008) and Innes \& Booher (2000) and analysis of policy implementation, the author tries to provide alternative models Kolobaratif Planning Tourism Development Program Implementation Tanah Laut district to achieve the effectiveness of the implementation strategy for tourism policy. Collaborative governance strategy is three-sector partnerships between government, the private sector, and community in the development of tourism policy that allows it to be implemented - a partnership of three sectors primarily driven by the mixing of the motive of self-interest by the desire to realize the common good.

The implementation of collaborative governance strategy opens opportunities for Tanah Laut regency government to develop local policies wisely. However, implementation of the policy has not been applied because the maximum capacity of the human and financial resources are adequate. Tanah Laut cannot rely on the performance of tourism development by relying entirely on the existing resources. Tanah Laut district government requires synergy with stakeholders. The concept of collaborative governance has a broader scope than the partnership. The highest scale of collaborative governance is to have a common view of the principle of partnership. Therefore, conceptually can be assumed that the partnership is the highest achievement of the stages of collaborative governance.

Research in Tanah Laut Regency showed that collaborative governance is implemented. The collaborative process requires high participation, equality of power, and the actors be competent. These ideal conditions look challenging to occur in people who have a low participation rate, inequalities of power and competence of tranquility. 
The role of democratic leaders become essential in the implementation of the collaborative program policy formulation. Leadership will be able to motivate all parties acting in the collaborative process. In line with the strengthening of democracy as a result of the development of science and technology, especially the Internet, the demands of IT-based transparency has also become an essential prerequisite for the implementation of the process of collaboration. Then the results of the collaborative process will be impossible for more quality; there should be an implementing agency with the involvement of all stakeholders.

Such thinking is a contribution to the process of collaborative research in Collaborative Governance models developed by Ansell and Gash (2007). Leadership is always the key to the success of collaborative policy formulation. Leadership is said to be the process of directing and influencing the activities that had to do with the job of group members. Three essential implications contained in this case are: (1) leadership it involves another person that subordinates or followers, (2) leadership involve distributing power between the leader and the group members equally, as members of the group is not without power, (3) their ability to use a different form of power to influence the behavior of their followers through a variety of ways. In essence, leadership is a process of influencing or give an example of a leader to his followers to achieve organizational goals (Veithzal Rival, 2003: 133). The formulation of the model shown in the picture below.

Figure 7.2 Model Implementation Planning Collaborative Tourism Development Program

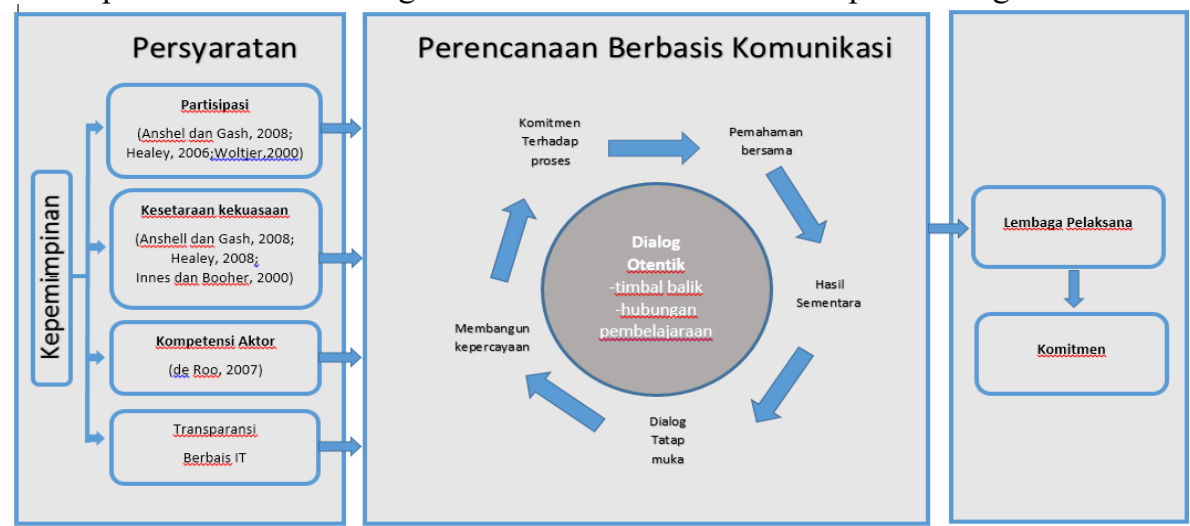

(Source: The results of our analysis to develop a model of Ansell \& Gash, 2008; Innes \& Booher, 2000 in Ely Sufianti, 2013)

Tanah Laut community is very firmly with paternalistic culture. Paternalism is a system that puts the leadership as the most dominant. Paternalism grows summer because it is influenced by the feudal culture that most areas in Indonesia. In a paternalistic society has a system of values, norms, and customs that always upholds and glorifies the authorities as a person who should be respected because they have given life and protection for the citizens.

In these cultures, there is a value on the importance of the role of employers in protecting subordinates. Thus a central role in community leadership paternalistic. The leadership style is a pattern of behavior the leader in directing, influencing, encouraging and control and give other people or subordinates motivation toward specific goals, both short term, and long term. This means that the style of leadership with a strong motivation to have power (Danim, 2004: 30).

Paternalistic type of leader who is widely available in the community environment that is still traditional, agrarian society generally. Popularity leader paternalistic in society thus be caused by factors such as the strength of primordial ties, extended family systems, community life communalistic, the role of customs is powerful in the life of society, it is still the possibility of an intimate personal relationship between the individual members of the community with community members more, Paternalistic leadership traits are:

1) Leaders capable of acting like a father.

2) Overly protective.

3) Decision making on the self-leadership.

4) Always be omniscient and omnipotent correct.

5) Rarely provide the opportunity for subordinates to develop creativity and imagination, innovation.

6) Demanding workflow or work process by what has been there and executed.

Organizational values espoused paternalistic leader:

The increasing quality of the people in a democracy and the IT course paternalistic style left with a transparent begin opening up to collaboration. Healey (2006), stated that the collaborative planning of the institutional aspects that system (governance), in a situation of power among the various stakeholders. For the importance of the initiator, stakeholders, where the lead role as an initiator which can drive the interests and involvement of stakeholders. It is said Healey; a leader is a significant initiator in the process of policy innovation through the process. 
To put it more simply, collaborative leadership is intended as a mechanism of governance arrangements mutually beneficial relationship between two or more parties who work toward a common goal by sharing responsibility, authority and accountability for results. Even though collaborative leadership has become a claim and be the ideal leadership model which should be guaranteed by a stronger legal mechanisms.

\section{Research Finding}

As a result the policy development of tourism in Tanah Laut Regency formulated with a top-down manner without involving community participation. Policy and 2017 have not been implemented optimally. Although not yet implemented no severe criticism of society. It happened because of the people of Tanah Laut regency still sticky with paternalistic culture. Regents to act more as a paternalistic leader to run governance by his will. Consequently a relatively low level of public participation for their inequalities of power. In the district of Tanah Laut occur politicization of bureaucracy and abuse of authority and integrity of the policy elite imaging lower officials.

In most cases, the coordination occurs between the Department of Culture in Tanah Laut District with the relevant authorities are not well established in coordination with the Planning Board (Bappeda), which is in the planning process, the Department of Public Works (PU) is in the form of infrastructure development other support, the Office transportation plans road construction, marine transport route plan, and Diskominfo that discusses the provision of telecommunications providers network aimed at keeping tourists are always connected to the internet network and a media access to promote local tourism.

This is implies that the communication and dissemination of policy implementation in the development of tourism promotion activities are still minimal. Forms of government support Tanah Laut not optimal in the development of tourism. In particular social, economic, political and are not conducive to the main problem of the failure of policy implementation.

\section{Conclusion}

To summarize the Tourism Development Policy Implementation in Tanah Laut Regency has not run optimally; the results still need improvement are considered standard and appropriate policy targets yet. Can be seen from the cooperation and coordination between the government and the public has not been maximized. Conflicts arise in the management of coastal attraction in Tanah Laut Regency. Inadequate facilities and infrastructure. Human resources support resource development of tourism in Tanah Laut Regency, but generally not professional and have not received adequate financial support from the government. Aspects of social, economic and political Attraction region Tanah Laut Regency available yet support. Disposition aspect, also not shown poor results as well.

Obviously, based on the research field found that the factors support them in the development of natural tourist attraction Land of the Sea, has been the policy in the form of regional regulation of tourism development, has been the foundation and structure of work contained in the duties and functions of the principal constitutionally. Furthermore, their authority to formulate and to establish and management of sources of funding and resources, geographical location, has a wealth of natural attractions, cultural and artificial tourism, culture, openness to the community rating, the security situation is good, has a variety of unique / attractions.

\section{BIBLIOGRAPHY}

Agiomirgianakis, G., Serenis, D., \& Tsounis, N. (2017). Effective timing of tourism policy: The case of Singapore. Economic Modelling, 60, 29-38. https://doi.org/10.1016/j.econmod.2016.09.001

Andrades, L., \& Dimanche, F. (2017). Destination competitiveness and tourism development in Russia: Issues and challenges. Tourism Management, 62, 360-376. https://doi.org/10.1016/j.tourman.2017.05.008

Ansell, C. and Gash, A. (2007). Collaborative Governance in Theory and Practice. Journal of Public Administration Research and Theory.

Allmendinger, P. (2001) Planning in the Post Modern Times. London: Routledge.

Bianchi, R. (2018). The political economy of tourism development: A critical review. Annals of Tourism Research, 70(June), 88-102. https://doi.org/10.1016/j.annals.2017.08.005

Bogdan and Biklen, (2007), Qualitative Research for Education, An Introduction to Theories and Methods, 5th edition, Eyracuse University

Bungin, Burhan. (2012). Qualitative Research Data Analysis. Jakarta: King Grafindo Persada.

Creswell, John W. (2009). Research Design: Qualitative, Quantitative, and Mixed Methods Approaches — third Edition Sage Publications. The USA.

Deng, T., Hu, Y., \& Ma, M. (2019). Regional policy and tourism: A quasi-natural experiment. Annals of Tourism Research, 74(777), 1-16. https://doi.org/10.1016/j.annals.2018.10.001

Drakulić Kovačević, N., Kovačević, L., Stankov, U., Dragićević, V., \& Miletić, A. (2018). Applying destination competitiveness model to strategic tourism development of small destinations: The case of South Banat 
district. Journal of Destination Marketing and Management, 8(September 2015), 114-124. https://doi.org/10.1016/j.jdmm.2017.01.002

Dredge, D., \& Jamal, T. (2015). Progress in tourism planning and policy: A post-structural perspective on knowledge production. Tourism Management, 51, 285-297. https://doi.org/10.1016/j.tourman.2015.06.002

Estol, J., \& Font, X. (2016). European tourism policy: Its evolution and structure. Tourism Management, 52 , 230-241. https://doi.org/10.1016/j.tourman.2015.06.007

Gardiner, S., \& Scott, N. (2018). Destination Innovation Matrix: A framework for new tourism experience and market development. Journal of Destination Marketing and Management, 10(November 2017), $122-131$. https://doi.org/10.1016/j.jdmm.2018.07.002

Healey, P., (1997), Collaborative Planning, Shaping Places In Fragmented Societies. Palgrave Macmillan. New York.

Innes, JE, and Booher, DE (2010) Beyond Collaboration Democratic Governance for a Resilient Society, in Planning with Complexity, An Introduction to collaborative rationality or public policy. Oxon: Routledge.

Korten, David C. and Ambassador. (1980). Dimension Development of Democracy, Obor Indonesia, Jakarta.

Lin, D., \& Simmons, D. (2017). Structured inter-network collaboration: Public participation in tourism planning in Southern China. Tourism Management, 63, 315-328. https://doi.org/10.1016/j.tourman.2017.06.024

Mai, T., \& Smith, C. (2018). Scenario-based planning for tourism development using system dynamic modelling: A case study of Cat Ba Island, Vietnam. Tourism Management, 68(April 2016), 336-354. https://doi.org/10.1016/j.tourman.2018.04.005

Martínez, R. M., Galván, M. O., \& Lafuente, A. M. G. (2014). Public Policies and Tourism Marketing. An Analysis of the Competitiveness on Tourism in Morelia, Mexico and Alcala de Henares, Spain. Procedia Social and Behavioral Sciences, 148, 146-152. https://doi.org/10.1016/j.sbspro.2014.07.028

Moleong, M, A. (2004) Qualitative Research Methodology. Bandung, Youth Rosdakarya.

Rittel, HW and Webber, MM (1973) dilemmas in a General Theory of Planning. Policy Sciences 4, 155-169.

Sabatier, Paul. (1986). "Top-down and Bottom-up Approaches to Implementation Research" Journal of Public Policy 6 (Jan), p. 21-48.

Tewdwr-Jones, M. and Allmendinger, P. (2002) Conclusion: Communicative Planning, Collaborative Planning, and the post-positivist Landscape Planning Theory. In Tewdwr-Jones, M., and Allmendinger, P. (Ed) Planning Futures; New Directions for Planning Theory, 206-216. London: Routledge.

Wang, L., \& Yotsumoto, Y. (2019). Conflict in tourism development in rural China. Tourism Management, 70(August 2018), 188-200. https://doi.org/10.1016/j.tourman.2018.08.012

First Author, Sihabuddin Chalid, born in Hulu Sungai Tengah, on April 8, 1965, currently completing his doctorate at the University of August 171945 in Surabaya, at the Doctoral Program in Political Social Sciences, Public Administration Study Program, until now a Member of the State Polytechnic Board of Trustees Tanah Laut since Th. 2017. Aside from being a lecturer at Politala Tanah Laut, also the Board of Trustees of the Tanah Laut Kabupatin Education Board, the author can be contacted via email csihabuddin@yahoo.com Second Author, Bambang Koesbandrijo, was born in Ponorogo, on May 3, 1963, had studied at Gadjah Mada University in 1991, now a University Lecturer on August 17, 1945 Surabaya, email bk.untag@gmail.com 